\title{
INTERNATIONALIZATION OF TURKISH SOAP OPERAS: A QUALITATIVE ANALYSIS ON TURKISH SOAP OPERA EXPORTERS
}

\section{Behiye BEĞENDİK ${ }^{1}$}

\begin{abstract}
Turkish soap operas have scored great success both in the home country and also in Middle East and Balkan countries since 2000. Through these achievements, Turkish soap operas were exported over the value of 300 million dollars. Also soap operas were broadcasted more than 150 countries. Turkey, as being soap opera importer previously, evaluated these numbers as a great success. The success of Turkish series exports attracts the attention of academicians as well as series producers and exporters. Thus, in this article it is aimed to explain the reasons of the success of Turkish soap opera internationalization.

Qualitative research is done on five firms exporting Turkish soap operas. According to the results of the study, the most important reasons of successful internationalization of Turkish soap operas are the cosmopolitan Turkish culture and the high quality of Turkish soap operas. However, the possibility of carrying this opportunity upwards was also achieved through proactive distribution. Proactive distribution has been realized as a result of marketing activities of distributors with high effort.
\end{abstract}

Keywords: Coding, qualitative analysis, international marketing, soap opera internationalization

JEL Classification: M16, M31, M39

\section{TÜRK DİIILERINIIN ULUSLARARASILAŞMASI: TÜRK DİŻ İHRACATÇILARI ÜZERİNE KALITTATIF ANALIZZ}

\author{
$\ddot{O} z$
}

Türk dizileri 2000 yılından bu yana Orta Doğu ve Balkanlar'da büyük başarılar elde etmiştir. Bu başarılar sayesinde 300 milyon \$'lık ihracat değeri ve 150'den fazla ülkeye dizi ihraç etme firsatı yakalanmıştır. Geçmişinde dizi ithalatçısı olan Türkiye için bu rakamlar büyük başarı olarak kabul edilmektedir. Türk dizilerinin ihracatından elde edilen başarı dizi üreticileri ve ihracatçılarının yanı sıra akademisyenlerin de ilgisini çekmektedir. Bu nedenle, bu makalede Türk dizilerinin uluslararasılaşma nedenleri araştırılmıştır.

Beş dizi ihracatçısı ile görüşülerek kalitatif çalışma gerçekleştirilmiştir. Araştırma sonuçlarına göre Türk dizisinin ihraç edildiği ülkelerde kendisine yer bulmasının en önemli nedenleri kozmopolit Türk kültürü ve Türk dizilerinin yüksek kalitede olmasıdır. Bununla birlikte bu fırsatı yukarılara taşıma imkanı da proaktif dağıtım sayesinde yakalanmıştır. Proaktif dağıtım dağıtımcıların yüksek çaba ile yaptıkları pazarlama faaliyetleri sonucunda gerçekleşmiştir.

Anahtar Kelimeler: Kodlama, Kalitatif araştırma, uluslararası pazarlama, Türk dizilerinin uluslararasılaşması

JEL Sinıflaması: M16, M31, M39

1 Asst. Prof., Beykoz University, Civil Aviation Scool, Aviation Management, behiyebegendik@beykoz.edu.tr, ORCID ID:0000-0002-7615-2049 


\section{Introduction}

The current economic climate has brought internationalization to the fore as a key strategy for surviving (Puig et al., 2014: 654.) The opening of markets has created the potential of expansion and investment for small and medium enterprises (Zapletalová, 2015: 1). Thus, access to the global market is able to enhance the regional growth and development.

Since the boarders got up from all over the world, business environment has an important strategic growth option like international market expansion. During recent years, a significant development within the broad internationalization trend has been the increasingly active role played by (Lu \& Beamish, 2001: 565) the firms from all sizes and from all sectors. Media is one of these sectors that is affected from internationalization and globalization. Since the mid-1980s broadcast media have gone from being exporters of television programmes to transnational corporations with overseas operations (Shrikhande, 2001:147).

Turkish media started the international ties with other countries initially importing soap operas, programme formats. After first experimental exports of soap operas, Turkish soap operas got a snowball effect across the Middle East countries, Balkans and Turkic Republics. It is stated that Turkish soap operas are watched in more than 150 countries with 400 million audiences. Thus, this unforeseen success attracts the media and the academicians. The news about Turkish soap operas takes places not only in national media but also in the international media. The academicians write articles based on Turkish soap operas looking from different perspectives. Authors interested in the popularity of Turkish soap operas especially in Arab countries. Kraidy and Al-Ghazzi (2013a) relates the rise of Turkish soap operas with the geopolitical underpinnings and geocultural consequences of transnational media flows. Similarly, in some articles the rise of Turkish soap operas is associated with the cultural ties of the exported countries (Kaptan, 2013; Dogramac1, 2014; Ileri, 2012; Uysal, 2012).

Some articles are focused only on the soap operas Noor and Magnificent Century (Hajjaj, 2013). Like the others Buccianti (2010), putting the Noor on the centre of the article, describes Turkish soap operas' triumph and introduces the various repercussions that resulted from it. Kuyucu (2014) searched the effects of Turkish series to Greek audience and its advantages to Turkey on the example of a soap opera exported to Greece, called Magnificent Century.

On the other hand, some authors (Kalın, 2009; Al-Ghazzi \& Kraidy, 2013b) related soap operas with foreign policy. Aida M. Yehia Salah El Din (2012) emphasized the impact of soft power represented in culture on the relationship between Turkey and the Arabs. Adrian Staudacher (2009) suggests that soap operas have a constant effect on Turkish- Greek peace with the example of Foreign Groom broadcasted from 2005-2007 on Greek TV channel. Correspondingly, Brljavac (2011) stated that due to the Ottoman heritage, the Turkish soap operas find very important place in Balkans' media. Egresi and Kara evaluate the factors that have influenced the direction of Turkish Foreign Direct Investment, concluding that economic factors have played a lesser role and, for the most part, countries were selected for cultural and political reasons. In the context of cultural reasons, they also gave a share for Turkish soap operas, contributing to Turkey's soft power even in societies such as Bulgaria, Greece and Serbia where negative attitudes towards Turkey and Turks continue to prevail (Egresi \& Kara, 2015: 194). 
Another perspective, examined in the articles, is the wish to visit Turkey, which generated by the Turkish soap operas' audiences all over the world. Ball, Ballı and Cebeci (2013) emphasizes the role of the exported soap operas in affecting Turkey's international tourism demand. Nuroglu has also analyzed the impact of Turkish series on the decision of coming to Turkey via a survey done among 88 tourists in Istanbul, Trabzon and Bursa. This article concludes that Turkish TV series have a positive impact on the decisions of the people with whom they conducted the survey (Nuroglu,1).

Although internationalization of soap operas investigated in social, politics and tourism subjects, one area is still neglected. The production companies or the distributors sell these soap operas to approximately 150 countries in the Middle East, Balkans and Central Asia and, more recently, in Latin America. In 2018 Şekip Avdagiç, the president of Istanbul Chambers of Commerce declarate that 300 million \$ income has obtained from exported more than 150 soap operas (https://www.haberturk.com/turk-dizileri-300-milyon-dolarlik-ihracat-yapiyor2179942-ekonomi). Although Turkish soap operas are considered a growing export item under Turkish export industry (Ball1 et al., 2013: 2), there is no attention on the international business literature about exporting of Turkish soap operas. Thus, in this article Turkish soap opera export is studied through the window of international business. This article's aim is to prove the position of Turkish soap operas in the international arena, dealing with the reasons of this success.

This study first explains the Turkish broadcast life and the history of Turkish soap operas in the national broadcast. Secondly, the rise of Turkish soap operas in the international arena is discussed. And finally in the research part, the reasons of the success of Turkish soap opera in the international media market and the effects of this success' to Turkey is studied through the in-depth interviews with the Turkish soap opera exporters.

\section{Media Internationalization}

Moran (2013) classified media internationalization since the 1930s in terms of four periods. In 1936 the live broadcasting was started in London (Penpece \& Y1lmaz, 2014:2). Through the end of the first period, by the mid-1950s national television networking services had also begun, or were about to start in Western Europe, North and South America, and Australia. Imitating programme ideas-mostly derived from the United Kingdom and the United States-became widespread across this international sector (Moran, 2013:5). During second stage, years between 1955-1980, the programme imports had begun. With United States and United Kingdom selling the television services to the other countries market expansion was also started in this stage. In the third stage (1980-2000) European television is entered into the world of formats. Broadcast services begin to commercialize and go to private by technological development. Multichanneling, the search for lower-cost content to fill expanded schedules and licensing of format programmes were seen in this stage. The contemporary phase of television programme format development has become the global or transnational stage of the television programme format industry (Moran, 2013: 10). As an example 'Who Wants to Be a Millionaire?' airing in around 160 countries worldwide has enormous successes in key markets. 


\section{History of Turkish Soap Operas}

To understand the critical rise of Turkish soap operas, it's essential to have information about the history of Turkish soap operas. In Turkey, television broadcasting and introducing television to public is occurred in 1968 when TRT (Turkish Radio and Television Institute) was founded. Turkish television broadcasting was in the monopoly of TRT till the first private television channel was founded. At the present, many national and local television channels are served in Turkey (Penpece \& Y1lmaz, 2014: 2). Turkish audience, being accustomed to listen serials on radio, have given special importance to dramas since the first television broadcasts.

Turkish audience has first met series with foreign-origin series like 'Dallas' and 'Little House on the Proirie', 'Bonanza, The Avengers, 'Commissar Columbo', 'Space 1999', 'Charie's Angels', which were imported from USA, England and France (Kuyucu, 2014: 104). The imported series were so popular that this was the fact to give importance to national TV dramas. The first Turkish series, Kaynanalar, was produced in 1974 by TRT. In 1980s although a serious increase in number is seen across the Turkish productions, TRT both produced and imported series. In 1990s the Turkish series were the most appreciated programme style after the main news bulletin. According to findings derived from Television Watching Habits Research of Radio and Television Supreme Council (RTUK) covering the period between 2006 and 2008, domestic series have been determined as mostly-watched programmes after prime news with percentages of \%88, 1 in 2006 and \%86, 2 in 2008 (Kuyucu, 2014: 109). Additionally, according to the opportunities of commercial broadcasting and competence conditions, Turkish series production accelerated in the middle of the 1990s (Tanriöver, 2010: 44). Since the rise of Turkish series in 1990s, it becomes a major employment-generating sector in Turkey, including producers, directors, actors, screenwriters, grips and gaffers (Karlıdağ \& Bulut, 2014: 84).

The quality of these series got higher through the increasing demand and competence between the production firms. Thus, the each episode appears and has the same quality as the foreign films, costing minimum $500.000 \mathrm{TL}$. Calinos, the company that started as a firm marketing pink series, American films, documentaries and cartoons to Middle Asia Turk Republics, predicted to export Turkish series to Middle Asia. They exported Crazy Heart in 2001 to Kazakhstan. The producer of the series demanding the technique cost and license cost only 1 \$ facilitated the first experience of selling the series. Thus, matching with the current price an unbelievable sale agreement was conducted, $30 \$$ per episode. On the other hand, through the interviews, it is admitted that there are two breaking points of Turkish series exports. Noor, announcing the presence of Turkish soap operas, provide the other soap operas to enter Middle East. By the way to prove the importance of this soap opera, it must be stated that the final of Noor is watched by 85 million people in the Middle East. At the same time Noor entering the Arab world, One Thousand and One Nights was exported to Bulgaria, Croatia and Greece. Experiencing different countries the exporter of the One Thousand and One Nights, opened Turkish soap operas through different sides of the world.

\section{Conditions in the Home Market}

In Turkey there are 31 national television channels which broadcast terrestrial, clear session and common. However 7 of them broadcast soap operas steadily (Tanriöver, 2010: 45). By the reason of being most demanded programme style, each of the channels broadcast a soap opera after news bulletin, in prime time. 
Prime time has the critical importance to get the income from companies that give advertisements according to ratings. Due to the new rating system, the Turkish television channels working a more competitive market. Thus, when a soap opera cannot get the high ratings, no matter how it is qualified or how the popular actresses and actors play, the channel management decide to end the soap opera. However the final of the soap operas doesn't change the general 'soap opera climate', for the new ones will come instead of the soap operas going off the air (Tanriöver, 2010: 48). As is seen from Table 1, the number of series broadcasted on weekly broadcasting streams of most-popular television channels is very high (Kuyucu, 2014: 108).

Table 1.1 Number of Domestic Series on Weekly Broadcasting Streams of Television

\begin{tabular}{|c|c|c|}
\hline Channel & Number of Series & Number of Prime Time Series \\
\hline Star TV & 53 & 5 \\
\hline Fox & 50 & 73 \\
\hline ATV & 44 & 7 \\
\hline TRT & 44 & 10 \\
\hline Kanal D & 41 & 7 \\
\hline Show TV & 19 & 54 \\
\hline Samanyolu TV & 17 & 7 \\
\hline Total & 268 & 7 \\
\hline
\end{tabular}

The Turkish television market is extremely competitive and ratings-driven. By the reason of this violent situation, production companies work hard to take the quality of the soap opera up to go on broadcasting. In other words, the violence in rating competition, forces the producers to differentiate their products in quality. And through the foreign audiences noticing this quality, alternative markets are occurred for the producers to recoup their costs (Yesil, 2015: 45).

\section{Research}

Since the Turkish soap operas became a phenomenon all over the World, the authors are interested in this subject through different perspectives. They emphasized especially the reasons of this sudden and international rise. The authors have an aim to relate this sucess with cultural ties (Kaptan, 2013; Dogramac1, 2014; Ileri, 2012; Uysal, 2012; Aida M. Yehia Salah El Din 2012). In their article Kalın 2009, Al-Ghazzi and Kraidy, 2013b evaluated this success of soap operas associating with the foreign policy. On the other hand, some authors studied on results of the expansion of Turkish dramas all over the world rather than reasons. Ball1 et al. (2013) mentioned the effects of Turkish dramas on tourism. As it is seen in the past articles, the subject about the expansion of Turkish soap operas is investigated in different ways. 
Soap opera internationalization is also the subject of international marketing. But although it has been more than 10 years, there is no article emphasizing the dimension of international marketing. Studying on the international marketing dimension of Turkish soap operas will present a deeper insight for the literature.

\subsection{The Purpose of the Research}

In the beginning of TV broadcasts Turkey didn't exist in the international markets as an exporter. Due to the competition among domestic TV channels in Turkey, producers searched for the possibility to export the soap operas. By the sale of some special soap operas like Noor, One Thousand and One Nights and Magnificient Century, the exports have changed the way through rapid spreading. Now, Turkish soap operas are considered a growing export item under Turkish export industry. Although Turkish soap opera export has a small amount relative to the total value of Turkey's export, it has become important part of the film producers' total sales. Thus, this shows that their role in foreign trade cannot be regarded as too little to undervalue. It's important to identify internationalization of Turkish soap operas taking an important role in foreign trade. And it's also important to identify the factors that affect the Turkish soap operas rapid rise in foreign markets. Thus, this paper investigates the subject Turkish soap operas' internationalization reasons, internationalization ways and the results after the internationalization has reached a particular degree, considering internationalization as a process.

\subsection{Research Model and Scope}

With the national success of soap operas, producers have turned their eyes to foreign markets. After the exportation of some special series, internationalization became rapidly. While examining the reason of the Turkish soap operas internationalization, this paper focuses the distrubition of soap operas looking from the window of international business area. Thus, one must also acknowledge that this would not have been possible without the integration of Turkish distributors into the global networks of television trade. As, Bielby and Harrington (2008) and Kuipers (2012) note, buyers and sellers are the main actors in the 'diffusion of programs and practices into national television industries and, from there, to people's living rooms' (Yesil, 2015: 53).

As mentioned below, this paper emphasizes the reasons of Turkish soap operas internationalization focusing on international sales and distribution and also identifies the results of internationalization of soap operas. And research method is shaped according to the model on Figure 5.1. This model is formed through the studies about the articles on the internationalization of Turkish soap operas. 


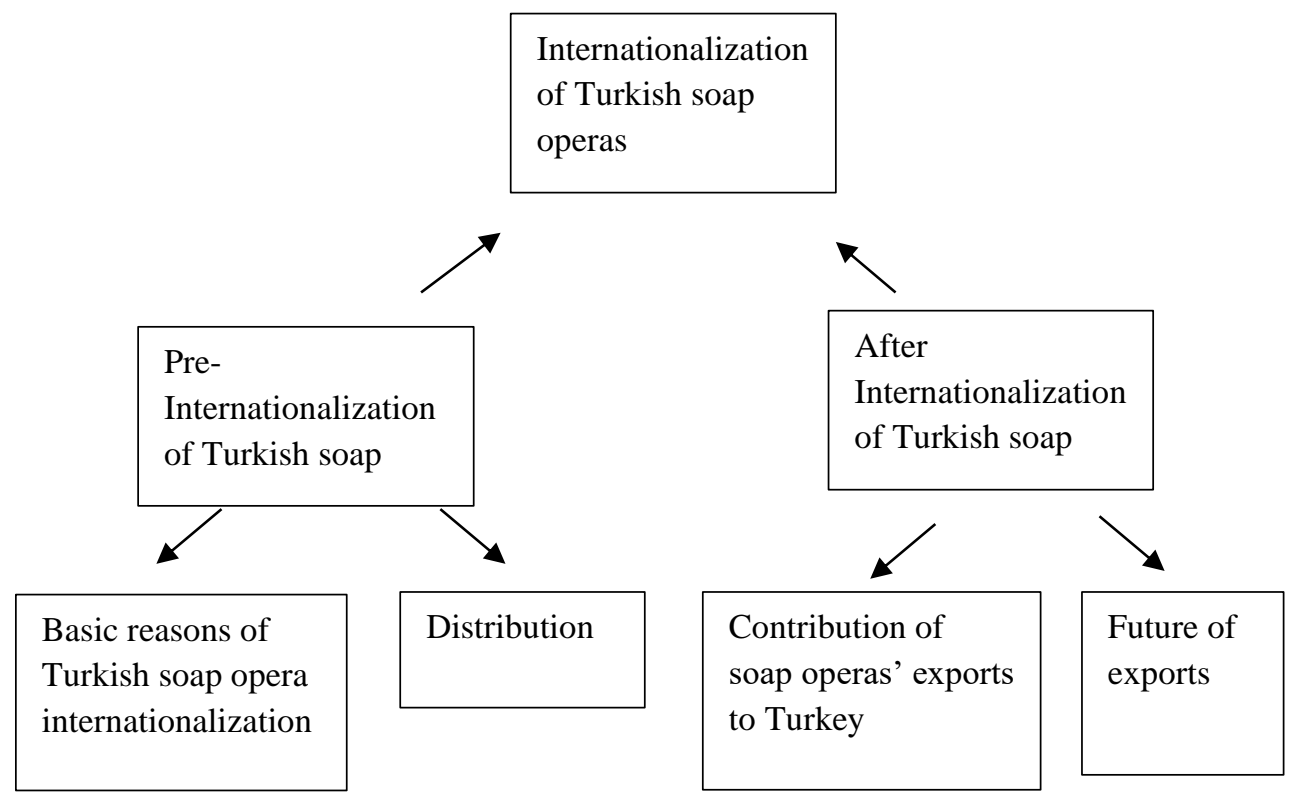

Figure 5.1. Model of Turkish Soap Opera Internationalization

In the scope of study, the distributors of Turkish soap operas are reached by the orientation of one of the producers. Three of them are exporters. The other two of them are the channel's export departments. All of the five firms accept to make face to face interview. The sample quantity is appropriate according to the 3-12 range in Yin and Eisenhardt' study.

\subsection{Research Method}

Qualitative research methods are applied, to develop a deep insight about the posture and events that represent research problem, to solve the problem and to ensure understanding the research problem better. Qualitative research methods are case studies, experiments, analysis of archives. In this article multiple case study approach is used, following Yin.

In case study, data can be gathered from different sources like: documentation, archives, interview, direct observation, and participant observation. This investigation is actualized by face to face interview.

Before evaluating the data gathered, it is required to register the data, to classify and to edit (Mayring; 2000: 72). Face to face interview is done with 5 soap opera exporter. The interviews ranged in time from 40 to 60 minutes. The interviews were recorded and then transcription step was done. The research was supported by secondary data, by gathering information from sources like financial data, firms' presentation, product definitions, web sites, and news from media. By the help of secondary data, the construct validaty of the study was increased.

The most difficult part of qualitative research is data analysis. Every research carries different properties and same analysis methods cannot be used (Yıldırım \& Simsek, 1999: 156). Thus, coding, one of the analysis of qualitative research, is preferred in this study. The purpose of coding is, finding the matter lying under the complexity and untidiness of data and conceptualizing it (Bas \& Akturan, 2008: 73).

Coding is the vital point of qualitative research (Babbie, 2004: 376). Coding is composed of three stages. These stages are listed as below: 
Open Coding: In open coding, data is separated in different pieces, investigated closely, compared for the purposes of similarities and differences. Thus, big data groups are shortened and obtained navigable pieces. (Corbin \& Strauss, 1998: 121).

Axial Coding: The key words with same and similar meanings are grouped and data is shortened (Corbin \& Strauss. 1998: 142).

Selective Coding: It is the process of developing and refining the theory. In developing theory, categories are organized arround the central explanatory concept (Corbin, \& Strauss,1998:161).

Analyzing data by coding is done with codebooks. Codebooks are lists that codes are organized simply. In codebooks; questions, answers, the selected part of the answer, and the codes take place.

During finding codes, techniques like repetitions and linguistic connectors are used (Bernard \& Ryan, 2010). Nonetheless, descriptive analysis is used to help coding. Descriptive analysis is summarizing and interpreting data according to the determined themes (Y1ldırım \& Simsek, 2008: 224). In the study, to reflect the participants' opinions, direct citations take place frequently.

At last in data analysis taxonomy is used. Taxonomy is the model that a group of concepts are related with eachother (Bernard \& Ryan, 2010: 139). Taxonomy has a view like hierarchical tree diagram (Denzin, 2000: 772).

\subsection{Reports of Research Findings}

It is more proper to start data analysis with evaluating the profiles of interviewed firms. Calinos is the first firm exporting Turkish soap operas to abroad for trial, while marketing American films, pink series and documentaries to Turkish Republics since 1997. Intermedya is established in 1992 and activity origin is importing Hollywood products to Turkey, East Europe and Soviet Union. Global Agency is established in 2006 and started exporting Turkish formats to abroad in 2008 after exporting the books of Turkish authors. And the other two firms ATV and Kanal D are national broadcast channels established in 1993. They started exporting Turkish soap operas in 2010.

In the first part of the interview form, there are questions about firms. In the following parts there are questions about the general information about the Turkish soap opera exports. Each answer is read for several times. By the techniques of repetitions and linguistic connectors, codes are found for again each answer. After open coding is ended for all answers, codes are listed. Codes that have same or near meaning, are incorporated into a common code that summarize them. Thus, number of codes are shortened by this way. And this operation is called as axial coding. At the end, all the codes are read again. And the codes that are related about our subject are chosen.

\section{Results}

Study results are gathered into two groups according to formation time. The first group is formed before Turkish soap opera exports. In other words, the first group, consisting of two aspects, have positive effects to begin exporting Turkish soap operas. Under the first item of first group, basic reasons of soap opera internationalization is gathered. First group's second item is about proactive distrubition. 
And the second group, consisting again two aspects, are seen after Turkish soap opera exports. First aspect of the second group is future of soap opera export. Second aspect is contribution of soap opera export to Turkey. The result of the study is summarized in the Figure 6.1. below.

According to the research results, reasons of soap opera internationalization is gathered under the headline of basic reasons. Basic reasons can be listed as actors and actresses, easier international trade, entering foreign markets with good soap operas, Turkey's politics of expansionism, good working distributors, high investments on soap operas, high production quality, Istanbul, script, form audience, raising Turkish soap opera image, snowball effect, suitable formats for family, Turkey's role model position, Turkish culture, Turkish women seen role model by Arabic women, unique contents, well described emotions. According to the explanations of these basic reasons, it can be seen that nearly all these reasons are the properties of soap operas.

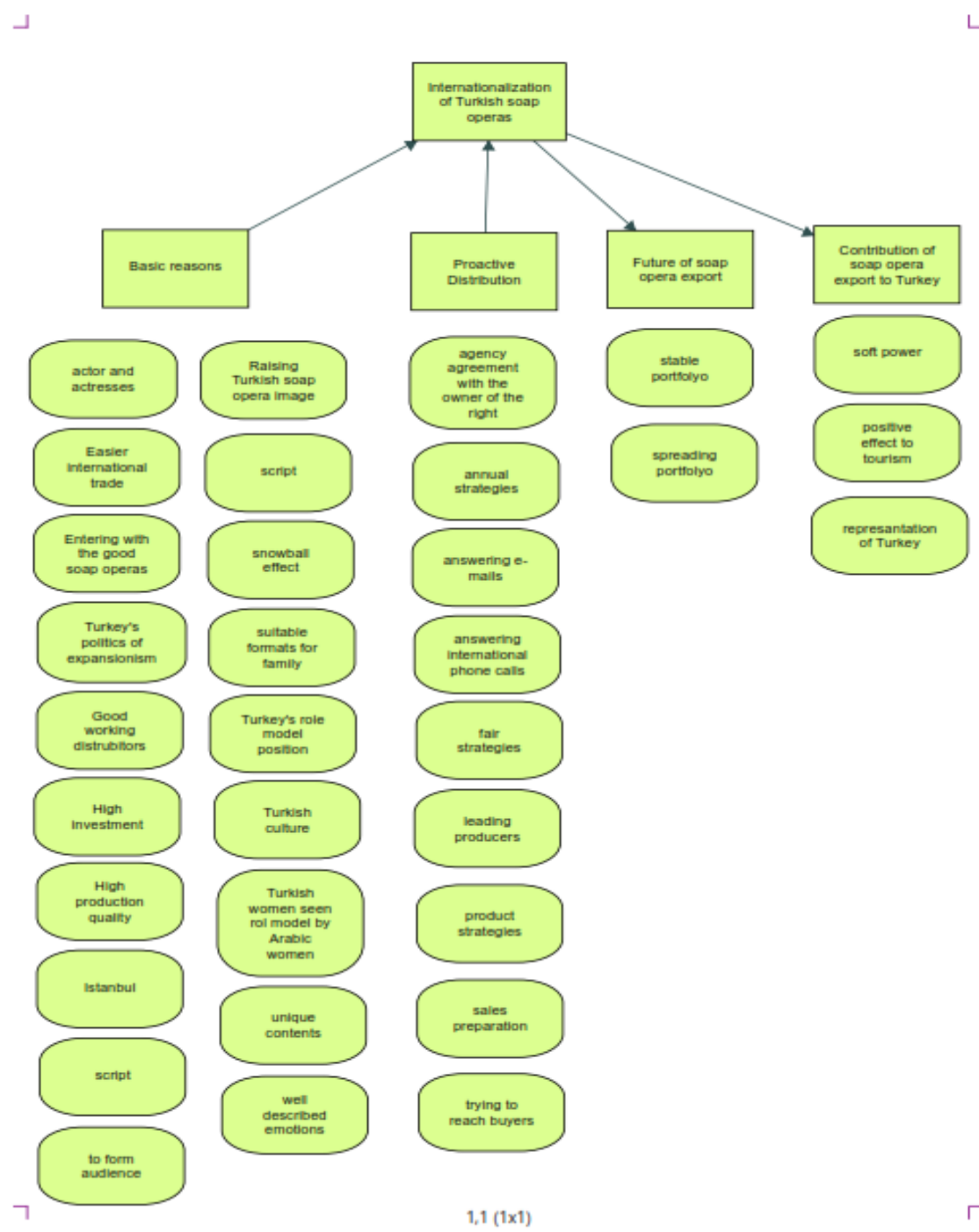

Figure 6.1. Reasons of Internationalization of Turkish Soap Operas 
Increasing popularity of Turkish soap operas in several markets makes the first subject of this research as basic reasons of Turkish soap opera internationalization. As in all the researchs about internationalization, it is admitted that international trade is faster with technological changes. Phone calls, internet, e-mails and web pages make easier Turkish soap opera exports for both buyers and Turkish distributors.

Among several reasons, the most important reason that affect Turkish soap opera internationalization and the only common point of five respondents is Turkish soap operas' high production quality. Turkish dramas are appreciated by the millions of audiences through the fascinating scripts, standing original and strong stories with well described emotions in the unique contents. At this point, in Turkish soap opearas emotions such love, jealousy, deception and conspiracy, all international and common senses are described so well that foreign audiences take their options from

Turkish soap operas among all other international productions. Compared with the science fiction American films or exxaggrated Latin America soap operas, Turkish soap operas are found suitable formats for family in exported countries. Together with the technical requirements, scripts supply the high production quality needed by Turkish soap operas to be in international markets. International revenues supplied producers to be able to do high investments which increases the quality of Turkish soap operas again. Especially compared with the exported countries' low quality soap operas, Turkish soap operas edge ahead as being appreciated by big crowd of audiences.

After Turkish film sector has reached the production quality of western products, Turkish dramas began to be preferred by the countries that have closed cultures with Turkey. At this point, Turkish culture is the second important subject for soap operas spreading. Both Middle East countries and European countries can find similar properties with their own culture. Similarity in culture, in music and also in life style makes Turkish soap operas closer for foreign audiences. This can be explained by the historical context streamed Ottoman Empirement. Beside historical context, with the cosmopolite culture Turkish dramas appeal east and west. Thus, Turkish dramas are exported to not only physically or culturally closed countries but also exported to the countries even having no common property like North America. Intermedya manager explained the importance and the effect of Turkish culture in soap opera internationalization as follows:

'We locate in the middle of everything. We are a little bit from Asia, a little bit from Middle East and a little bit from Europe. This has gone for centuries through generations. Inevitably we are affected from different cultures. Considering that our present popular culture is borned through the interactions of these different cultures, people from every culture can find something from themselves in our productions. Thus, we export soap opera to South America. We also export the same soap opera to Afghanistan. Two different cultures can watch the same soap opera. They watch the same soap opera with same appreciaition. We can say the reason of Turkish soap opera internationalization is the cosmopolite structure.'

Turkish culture has another indirect effects on Turkish soap opera internationalization. Through Turkey's position and modern Islamic life, it is obvious that Turkey is accepted as a role model by the Middle East countries. Turkey's political position together with the modern lives of women is admired by the Islamic countries. 
Intermedya manager identifies that, 'Arab women from Middle East see Turkish women as role model. They identify the soap opera characters with general Turkish women. Thus, the decision of Arab women is the the determining factor for Turkish soap operas to be admired.'

Also Istanbul is an important fact not to be ignored with the amazing charm beginning from our common history and still increasing by the marvelous images in Turkish dramas. These facts form a so serious crowd of audience that the channels of Middle East countries demand and also want to broadcast Turkish dramas simultaneously with Turkish channels. About this subject ATV manager states as follows:

'When a content enters in a market, that market begin to know you and forms a particular audience. In other words, forming particular audience makes preasure on buyers to continue to buy and broadcast Turkish soap operas again and again. This is also called as snowball effect.'

Related with new enterance, another reason that affect the internationalization of Turkish soap operas is choosing the right soap operas to enter a new market. The first soap opera in the new market determines a perception for the following soap operas. Right Turkish soap operas forming perception that Turkish soap operas are qualified and good, smooth the following soap operas in international markets. These audiences also begin to follow Turkish actor and actresses who have positive effect on internationalization. Through their high performances, Turkish actor and actresses Kıvanç Tatlıtuğ, Kenan İmirzalığlu, Murat Yıldırım, Tuba Büyüküstün, Beren Saat, formed big amount of fans. The expactations of fans for these famous actors and actresses supply continuity of the Turkish soap opera exports.

All of the above reasons of Turkish soap opera exports had already existed in current conditions in Turkey. These conditions were enough to realize the exports while demands come from the buyer countries. When the sales come to a point the producers and distributors began to implement marketing strategies for entering new markets. At this point, it has to be admitted that, Turkish dramas internationalization all over the world is performed by the good working distributors. Distributors have opened a great gate for film industry so that producers make higher investments gaining higher revenue from international sales. High investments means high production quality that has led a way to raise Turkish soap opera image in the international markets. Again it is distributors' success to attract audiences while new market entrance choosing the right soap operas.

Distributors insist on marketing Turkish dramas after they recognize the demand of international markets. However, undertaking the great responsibility of Turkish dramas internationalization, distributors have picked the export numbers to high levels. Thus, in this research the second fact that affect Turkish dramas internationalization is distributors' proactive activities.

Among all components, the most important fact to be proactive is distributors leading the film producers about the casting, location and the script through the contacts with the agencies of target markets. So that, producers make dramas suitable for exporting. The respondent from Intermedya tells as:

'Of course, the producers ask our thoughts. They talk about their project from the beginning. They give information about the casting, the location and the script. Because we touch the buyers. We know them the best. And we suggest them if you deal with this casting instead of their plan, our revenue in Middle East will increase. 
If you use bla bla locations, our sale chance in East Europe will increase. We transfer information that we gathered from our experience like that. They give attention. And they make regulations through our advices in their productions.'

According to distributors' advices producers form the new soap operas considering that these soap operas will be exported. Due to international sales, producers identify strategies for entering new countries. Among the near countries to Turkey, Russia, being conservative than the others, is the only country that exportation didn't occur. ATV manager states that Kurt Seyt\&Shura is totally concerned with entering to Russia. Kurt Seyt\&Shura is formed and shooted in Russia according to producer's plan to enter Russia market. And there are also other examples for soap operas shooted in foreign countries with foreign casts considering to attract audience in those markets. These strategies are also involved in proactive distribution as planned to spread new markets.

As mentioned before, the acceleration of internationalization period began by chance. The previous people in charge didn't give the required importance with unanswered phones and emails. Thus, channels and distributors got over their unprepared situation starting from answering phones and e-mails in the sense of becoming more proactive. Distributors make also soap operas' promotion activities. In the scope of international sales preparation, they make new catalogs, new web pages for buyers. Through the promotion activities in the fairs, the distributors maintain the increasing awareness of both buyers and the audiences. This is also directly related with the utility for the brand.

While analyzing the results some of the factors are founded to be related each other. Turkish soap opera tracked a rapid internationalization way. And some of the planned actions of soap opera industry actors accelerated this process. Thus these actions are gathered under another group of soap opera internationalization reasons named as proactive distribution. Agency agreements with the owner of the rights, annual strategies, answering e-mails, answering international phone calls, fair strategies, leading producers, product strategies, sales preperation, trying to reach buyers are all the headlines of soap opera distributers' actions.

It must be repeated that the basic reasons of soap opera internationalization depends the properties of soap operas. In other words the items, under basic reasons headline, are formed through mainly from soap opera producers. On the other hand, soap opera distributers work for soap opera exportation as different from soap opera producers. In this article saop opera distributers efforts are listed under the name of proactive distribution. The production of soap operas isn't enough for announcing the existence of soap operas to all over the world. There is serious marketing efforts for internationalization. Export activities need some proactive steps and strategies for marketing.

Distributors make agency agreements with the owner of the rights, who has the power to sell the soap operas in the international markets. Thus, the beginning point of proactive distribution for distributors is having the agency agreement with the owner of the rights. After having the rights, distributors plan annual strategies. Fairs' strategies are the subtitles of annual strategies and have importance for distributors at least meeting with the buyers and also presenting soap operas to target audiences.

On the other hand, the most important effect of fairs for distributors to give strategic decisions after examining the results of fairs. 
Thus, all the strategies, including the annual strategies, the fair strategies and the product strategies compose the proactive distribution, being the part of plans of soap operas' international spreading. As the Intermedya manager says:

'...We attend fairs which only professionals come together for commerce. Correspondingly our all work is moved there. We make strategies in terms of fairs and products. We collate them to find the better one. Last year we went fairs from China to Miami. It is not enough just going fairs. We give serious amount of advertisements in international channels. We go fests. We attend sectoral seminars as a speaker. And our total struggle is to show our works, our soap operas to target audiences in every activity.'

Consequently, fairs provide both the buyers and the distributors to have a relationship with eachother. As the manager of the ATV implies, this relationship results with so many positive effects including gaining trust.

'In the fairs, we meet with the people who want to see us face to face. It conduces some positive effects. They maintain opinion not only about your personality but also your quality being a salesman. They see how pretentious you are. And according to these you can gain confidence.'

As said before, during search analysis the process of Turkish soap opera internationalization is divideded in two groups, according to occurring time. The second group observed after the internationalization comes up to a particular degree. Based on the interviewers' answers, two results got out after the internationalization of soap operas. The first one is about future of Turkish soap operas internationalization. The interviewers of this investigation couldn't reach an agreement about the future of soap opera export. Thus, in this article it is rated in two different sight. First sight, composing of four interviewers, defends that Turkish soap opera portfolyo still continues to spread in the international arena. One of the reasons that this estimation based on, is continuity of Turkish soap opera attraction. The founder of Global Agency and the export responsible of Kanal D stated in the same way that the Turkish soap opera attraction continue by increasing day by day. And this situation lead to the export sales to reach a record level. ATV manager says as follows:

'2-3 years ago the attraction of Turkish soap opera was predicted to end in 2-3 years. But, at the present time again record sales are done. An artsy soap opera can be sold $400.000 \$$ or $500.000 \$$ per episode. There is so high demand that from the internet you can find the soap opera with Arabic subtitles within two hours. Consequently, soap operas should be broadcasted synchronously in especially Middle East. That is why the export numbers rised up.'

Increasing sales every year is another statement that supports the spreading portfolyo. The founder of Global Agency and manager of Intermedya both implied that soap operas are continued to be saled increasingly year over year and also that sector is still growing. Actually these answers are respected to be strong clues for continuing attraction. On the other hand, this popularity has begun and reached to this level without any effort or any investment for sales. When the increasing trend will slow down, in that case the distributors will change their working stylesto extend the soap operas lives in the international markets. This time distributors will support for continuity of soap operas attraction. Another fact related to this subject is purchasing countries of Turkish soap operas are verified day by day. In other words, new purchasers from new geographies, from new continents will open a new way for spreading. 
Global Agency founder exemplified this situation with entering South America market by the way of selling One Thousand and One Night to Chile. ATV manager added Pakistan, Ukraine, Georgia, Estonia and Latin America for giving examples of their spreading portfolyo.

On the contrary of spreading portfolyo, one of the participant, the founder of Calinos, defends that in the following period the Turkish soap operas will not be popular as of old. The variation in rating system engendered the rise of local and neighborhood comedy which has no chance to be admired in international arena. Accordingly, the number of exportable soap operas is decreased. Thus, soap opera exportation trends to be stable in the future:

'Due to the variation in rating system, there are serious problems in the production of exportable soap operas in Turkey. Predominantly broadcasted soap operas are rather the local and neighborhood comedies which have no qualification to be broadcasted abroad. Abroad countries want to see rather luxuary, magnificience, conspiracy, love, Istanbul etc. They don't follow the soap operas, that will be understood by local people, made in Antep or Karadeniz. Thus, the exportation of soap operas will end in 1 or 2 years.'

Although just one of the participants maintain the stable portfolyo, others have also supported some threats of spreading portfolyo throughout the interviews. The manager from Intermedya exemplifies as:

'In my opinion, the only and forthcoming threat for us is political reasons. Furthermore, we will go on our job. Nobody will pull ahead us. However, some political implementations can pull ahead us. ... Because of Turkey's Egypt politics, two of the firms that we market Middle East North Africa rights to, decided to boycott Turkish productions. They stopped to purchase. And also they cut the broadcast of Turkish soap operas that they bought and broadcasted. Correspondingly, the biggest revenue resource has closed down.'

ATV manager has some anxieties about difficulty in spreading portfolyo also. Furtherly, investments are needed to spread soap operas in the international markets. Also distributors have to take risks to spread portfolyos:

'The regions so far were the regions that we exported without extra investment. Here after, we have to do investments. For example,to be able to enter South Africa we have to make special dubbing. To enter more countries, you have to take risks as making a loss. Right now, we don't think like this. Nobody thinks like this. Because, as the soap opera begins to go on the air, it is sold to other countries without change and generates a revenue. We are not used to invest for abroad sales. We don't have this mentality. We earn this money without any struggles. Hereafter, ATV won't change its way. However there are some idealist producers and distributors. Moreover, they had big loss. To be able to enter Latin America, they made dubbing for 6-7 parts in Colombia. But it didn't work. Because of the Muslim demografic structure in Malaysia, Indonesia and Miammar they want to enter South East Asia. However the prices are so low. For me, we have come to an important and serious point. The following regions are not easy to spread. It is not easy to enter France, England or Italy. Maybe they will be able to enter these countries but through digital channels. We have come to this point in 7-8 years. The following part will not occur quickly.'

On the other hand, founder of Global Agency implied another point that will affect soap opera exports negatively. Global Agency founder states that the countries that import Turkish soap operas, begin to get rich. Their soap operas also begin to get higher in production quality. 
Thus, rivals from now on have local products. Consequently, according to Global Agency founder, as a growing sector every year the soap operas attraction will go on, even if a little decrease because of these negative situations.

Based on interviewers' answers, the second result observed after the soap opera internationalization is the contribution of soap opera export to Turkey. Being soft power, representaion of Turkey, positive effect to tourism are the items that composes the contribution of soap opera export to Turkey.

The first contribution is the positive effect to tourism, which can be seen in daily lives. It is estimated by the agencies that after the Turkish soap opera internationalization, the number of voyagers is increased approximately $25-30 \%$. Another statement that confirms the positive effect to tourism is the $350 \%$ increase in tourists from Middle East in last 5 years. This increase from Arabic countries in Middle East is relied on especially the Turkish soap opera effect. Thus, tourism agents added film sets as destination point and make Turkey trip more attractive for Arabs.

The most important contribution after the soap opera exports is representation of Turkey in the international arena. With 250 million audiences the soap operas are more effective than Turkeys advertisements. Correspondingly, ATV manager states although Turkey advertisements are produced with high budgets, they can't reach the number of audiences as soap operas and also they don't have the effect on audiences as powerful as soap operas'. Through exported soap operas, Turkey not only gains export revenue but also makes a self presentation without any costs.

Associated with the above aspect, Turkey has gained soft power, both among a cross-cultural audience and within the wider context of cultural, economic, and political influences. Other than the export sales, Turkey has catched a renewing effect for economy as the increase of interest for Turkish goods in broadcasted countries and the tempt to visit Turkey through the Turkish admirers. High and middle class tourist from petrol rich countries leave much more money than the tourists from Europe (Nuroğlu, 2013: 7). Similarly with the information from literature, the respondent from ATV talked about the current situation as follows:

'Soap opera effects are not limited with tourism. Concerned with the Turkey's location, the importance for us going to London is the same for Arabs going to Istanbul. There is a serious increase in real estate sales. All over the world, soap opera power is like our country. In Turkish soap operas the audiences see Bosphorus. There are sea cost and the latest design cars. Istanbul has become an appealing centre. Some of the audiences want to live in Istanbul, not just to visit for 1 week or a couple of days. Construction sector triggers 100 sectors automatically.'

Intermedya maneger also gave important information relate to this subject:

'200 million \$ revenue the monetary consideration of our international sales is the part that is seen on iceberg and drifts an economy that is around billion dollar. Think like that: From the beginning of 80 s to 2000s what is the effect of American products on Turkey, we do the same effect in Middle East, in Balkans and in Middle Asia. An important economy, tourism, health tourism etc. Our company is the distributor. The audiences send us e-mails asking where they can buy the dresses of leading roles or which firm produces the furniture of the bedrooms. It is a serious market. If the revenue gained from soap opera export is 200 million\$, then the total yield is billion dollars.' 
Besides the economical gain, soap operas achieved an unexpected case without any planned study. Turkish language is appealing audiences and they want to learn Turkish through Turkish courses. In Afghanistan, Turkish is the most spoken foreign language. Also the audiences from Iran and Syria are interested in learning Turkish. Before the political changes in Syria, number of Turkish language courses had reached a serious amount. Having a bend for languages, also the Balkan people see Turkish soap operas with subtitles as an opportunity for learning language (Nuroğlu, 2013: 8).

\section{Conclusion}

Turkish soap operas are followed by global audiences from 150 different countries, generate more than 300 million \$ revenue. Turkey's target in media sector is stated as 1 billion \$http://www.ito.org.tr/wps/portal/gazete-detay?WCM_GLOBAL_CONTEXT=ito_ portal_tr/ito-portal / gazete/gzt-2014gzt -2014-9/gzt-2014-9-26/a022d18045dd5 d5983e1ff174d181f0c). Le Soir from Belgium, implying global success of Turkish soap operas, determined that Turkey got in front of America in producting and exporting soap operas, referring Medimatrie Institute. Through these numbers, this time Turkey is admitted to be a global player in international media market as an exporter, not an importer. This revolution attracted the authors and leaded many investigations based on Turkish media sector from different perspectives.

This article expresses the internationalization period of soap operas in the simplest way, focusing on internationalization processes after the internationalization degree come to a serious point. The most important contribuition of this article is listing the before and after processes of Turkish soap opera internationalization in the same framework for reducing the complexity in the literature.

Firstly, this article organizes the basic reasons of Turkish soap opera internationalization according to the interviews with the exporters. High quality of Turkish soap operas together with the Turkish cosmopolite culture opened a place for Turkish soap operas in the exported countries that are poor in local products.

Secondly, differently from previous articles, in this article the successful distribution has been implied by the respondants. Soap opera distributors give serious efforts for exporting soap operas as different from soap opera manufacturers. As the distrubition is the subject of marketing, we can see this enormous success of soap opera internationalization comes from marketing efforts of distributors. Without marketing activities, it would not be possible to announce the existence of the Turkish series aside from the international success.

Thirdly, the contribution of soap operas to Turkey as renewing effect for the economy, representing Turkey and affecting tourism positevely is deeply expressed supported with the discourses of respondants.

Lastly, together with some problems, it is estimated that the popularity of Turkish soap operas will continue in exported countries. The variation in Turkish rating system, political problems resulting with boycotts of broadcasting Turkish soap operas and the local products in exported countries raised as the threats for Turkish soap operas spreading.

Consequently, soap opera export has emerged as an important item for both government and media sector. 
However, there is no strict information about the number of exported soap operas totally, the number of countries exports occured, or the number of soap operas exported to a particular country. It will be better to work on certain information for both producers and distributors to be able to move on strategic plans as operating in an international market. Being aware of film exports have rising value in the total exports of Turkey, Istanbul Chamber of Commerce aimed at helping exporters by editing the movie action plan for 2019. Aditionally, the alternative of MIPCOM, the exhibition held in Cannes, international fairs for marketing Turkish soap operas is aimed to be organized. Although these are useful steps for taking the export values higher, goverment should give neccessary attention to shape the direction of soap opera exports to continue with the attraction of the audiences.

Although this article has overviewed the basic framework of Turkish soap opera internationalization, there is still gaps in the literature. Even though there is some researches about the importer side, the majority of articles takes the subject from exporter side. The more researches on audiences in importer countries will express the subject better giving a deeper insight.

\section{References}

Aida M. Yehia Salah El Din. (2012). The impact of Turkish TV series aired on the Arab satellite channels on Turkish-Arab relations, culture and politics in the new middle east, first published 2012 in Ankara by institute of strategic thinking (SDE)

Al-Ghazzi, O., \& Kraidy, M. M. (2013b). Neo-Ottoman cool 2: Turkish nation branding and Arabic-language transnational broadcasting. International Journal of Communication, 7, 2341-2360

Babbie, E. (2004). The practise of social research, (10 th ed.). Belmont: Wadsworth / Thomson Learning.

Ballı, F., Ballı, H. O., \& Cebeci, K. (2013). Impacts of exported Turkish soap operas and visafree entry on inbound tourism to Turkey. Tourism Management, 37, 1-7

Bas, T., \& Akturan, U. (2008). Nitel arastırma yöntemleri- NVivo 7.0 ile nitel veri analizi. (Birinci Baskı). Ankara: SeckinYayıncılık

Beamish, P. W., \& Lu, J. W. (2001). The internationalization and performance of SMEs. Strategic Management Journal, 22, 565-586.

Bernard, H. R., \& Ryan, G. (2010). Analyzing qualitative data systematic approaches. California: Sage Publications.

Bucciant, A. (2010). Dubbed Turkish soap operas conquering the Arab world: social liberation or cultural alienation? Arab Media and Society, No: 10, 1-7.

Brljavac, B. (2011). Turkey entering the European Union through the Balkan Doors: In the style of a great power?, Romanian Journal of European Affairs, 11(2), 82-91.

Corbin, J., \& Strauss, A. (1998). Basics of qualitative research-techniques and procedures for developing grounded theory. (Second Ed.). London: Sage Publication.

Cereci, S. (2014). Türk televizyon dizilerinin küresel başarısı: evrensel insan yaklaşımı. Journal of Academic Social Science Studies, No. 28 pp. 1-12.

Denzin, N. K., \& Lincoln, Y. S. (2000). Handbook of qualitative research. (Second Edition). California: Sage Publication.

Dogramaci, E. (2014). A Revisionist Turkish identity: Power, religion and ethnicity as Ottoman identity in the Turkish series Muhteşem Yüzyll. London: London School of Economics and Political Science, Dissertation.

Egresi, I., \& Kara, F. (2015). Foreign policy influences on outward direct investment: The case of Turkey, Journal of Balkan and Near Eastern Studies, 17(2), 181-203. 
Hajjaj, N. A. (2013). Beyond critical communication: Noor's soap opera, Proceedings of 70th New York State Communication Association. Vol. 2012, Article 6.Turkish Soap Operas Influencing Arab Culture and Politics', The Peninsula, 21.07.2010

(http://www.ito.org.tr/wps/portal/gazetedetay?WCM_GLOBAL_CONTEXT=ito_portal_tr/ito-portal / gazete/gzt-2014gzt 2014-9/gzt-2014-9-26/a022d18045dd5 d5983e1ff174d181f0c)

https://www.haberturk.com/turk-dizileri-300-milyon-dolarlik-ihracat-yapiyor-2179942ekonomi

Ileri, B. (2012). Turkish cultural envoys on Arabic televisions, culture and politics in the new middle east. First published 2012 in Ankara by Institute of Strategic Thinking (SDE)

Kalın, I. (2009). Debating Turkey in the middle east: The dawn of a new geopolitical imagination? Insight Turkey, Vol. 11, No. 1, pp. 83-96

Kaptan Y. (2013). A conceptual perspective to media: Cultural globalization, clash of civilizations, or hegemony. Global Media Journal: Turkish Edition, Vol. 3, No. 7, 118 134.

Karlıdağ, S., \& Bulut, S. (2014). The transnational spread of Turkish television soap operas. Istanbul Üniversitesi İletişim Fakültesi Dergisi, 2014/II 47 75-96.

Kraidy, M. M., \& Al-Ghazzi, O. (2013a). 'Neo-Ottoman cool: Turkish popular culture in the Arab public sphere', Popular Communication, 11: 17-29.

Kuyucu, M. (2014). Evaluation of the economic and cultural effects of the Turkish soap operas and TV series exported to world TVs in the example of 'Muhteşem Yüzyıl' and Greece, 8-10 September 2014- Istanbul, Turkey, Proceedings of SOCIOINT14- International Conference on Social Sciences and Humanities, 103-122

Mayring, P. (2000). Nitel sosyal arastırmaya giriş. cev.: Adnan Gümüs, M. Sezai Durgun, Adana: Baki Kitabevi.

Moran, A. (2013). Global television formats: genesis and growth. Critical Studies in Television, Volume 8, No. 2, 1-19.

Nuroglu, E. (31 Ekim-1 Kasım 2013). Dizi turizmi: Orta Doğu ve Balkanlar'dan gelen turistlerin Türkiye'yi ziyaret kararında Türk dizileri ne kadar etkili? 5. Uluslararası İstanbul İktisatçılar Zirvesi, Küresel ve Bölgesel Değişim Sürecinde Yeni Türkiye'nin Ekonomik Vizyonu. İstanbul / Türkiye.

Penpece, D., \& Yılmaz, E. (2014). Demografik değişkenler ve dizi türünün dizi tanıtım mecralarına etkisi üzerine bir araştırma. İşletme ve İktisat Çalışmaları Dergisi, Cilt 2, Sayı 1, ss.1-10.

Puig, F., Gonza'lez - Loureiro, M., \& Ghauri, P. N. (2014). Internationalisation for survival: The case of new ventures. Management International Review, 54: 653-673.

Uysal, A. (2012). The Turkish soap operas in the middle east, as framed in the Arab media. Culture and Politics in the New Middle East, First published 2012 in Ankara by Institute of Strategic Thinking (SDE)

Shrikhande, S. (2001). Competitive strategies in the internationalization of television: CNNI and BBC world in Asia. The Journal of Media Economics, 14(3), 147-168.

Staudacher, A., (2009). Effects of popular discourses in Turkish-Greek peace. Researcher's relations annual meeting of the swiss political science association, 8 - 9 of January 2009, St. Gallen.

Tanrı̈ver, H. U. (2010). Türkiye'de film endüstrisinin konumu ve hedefleri. İstanbul Ticaret Odası Yayınları, Sektörel Etütler ve Araştırmalar, Yayın No: 2010-116.

Yesil, B. (2015). Transnationalization of Turkish dramas: Exploring the convergence of local and global market imperatives, Global Media and Communication, Vol. 11(1) 43 -60.

Yıldırım, A., \& Simsek, H. (1999). Sosyal bilimlerde nitel arastırma yöntemleri. (1. Bask1). Ankara: Seckin Yayıncılık. 
Beykoz Akademi Dergisi, 2019; 7(2), 31-49

MAKALE

Gönderim tarihi: 22.08.2019 Kabul tarihi: 25.11.2019

DOI: 10.14514/BYK.m.26515393.2019.7/2.31-49

Yıldırım, A., \& Simsek, H. (2008). Sosyal bilimlerde nitel arastırma yöntemleri. (7. Baskı). Ankara: Seckin Yayıncılık.

Zapletalova, Š., (2015). Models of Czech companies' internationalization. Journal of International Entrepreneurship. 